\title{
Effect of Casein and Propionate Supply on Mammary Protein Metabolism in Lactating Dairy Cows
}

\author{
G. Raggio, ${ }^{\star}$ S. Lemosquet,† G. E. Lobley, $\neq$ H. Rulquin,† and H. Lapierre $\S^{1}$ \\ *Department of Animal Science, Université Laval, Québec, Québec, Canada, G1K 7P4 \\ †Institut National de la Recherche Agronomique, Unité Mixte de Recherches Production du Lait, 35590 Saint-Gilles, France \\ ‡Rowett Research Institute, Aberdeen, UK, AB21 9SB \\ §Dairy and Swine Research \& Development Centre, Agriculture and Agri-Food Canada, Sherbrooke, Quebec, Canada, J1M 1 Z3
}

\section{ABSTRACT}

The effects of casein $(\mathrm{CN})$ and propionate $(\mathrm{C} 3)$ on mammary AA metabolism were determined in 3 multiparous Holstein cows fitted with both duodenal and ruminal cannulas and used in a replicated Youden square with six 14 -d periods. Casein ( $743 \mathrm{~g} / \mathrm{d}$ in the duodenum) and C3 (1,041 g/d in the rumen) infusions were tested in a factorial arrangement. For each period, L-[1$\left.{ }^{13} \mathrm{C}\right]$ Leu (d 11) and $\mathrm{NaH}\left[{ }^{13} \mathrm{C}\right] \mathrm{O}_{3}(\mathrm{~d} 13)$ were infused into a jugular vein, and blood samples were taken from the carotid artery and the mammary vein to determine Leu kinetics and net uptake of AA. Both $\mathrm{CN}$ and $\mathrm{C} 3$ treatments separately increased milk protein concentration and yield. With $\mathrm{CN}$ there was a general response in mammary protein metabolism, involving increases in Leu net uptake (30\%), the uptake:output ratio (8\%), protein synthesis (11\%), secretion in milk protein $(21 \%)$, and oxidation (259\%). In contrast, C3 treatments tended to increase only Leu in milk protein (7\%) and, when in combination with $\mathrm{CN}$, to reduce Leu used for protein synthesis (5\%). Across all treatments, most Leu uptake by the mammary gland was accounted for as Leu in milk or oxidized, and the Leu balance was therefore achieved without involvement of either net peptide use or production. Mammary uptake of group $1 \mathrm{AA}$ increased to match milk output with all infusions. In contrast, mammary uptake of group 2 AA exceeded output to a greater extent with $\mathrm{CN}$ than with $\mathrm{C} 3$ infusions, whereas the increment in uptake of group $3 \mathrm{AA}$ increased with $\mathrm{C} 3$ treatments. Overall, these data suggest that different mechanisms operate to improve milk protein production when either protein or energy is supplied.

Key words: casein, propionate, mammary gland, protein metabolism

Received January 27, 2006.

Accepted April 5, 2006.

${ }^{1}$ Corresponding author: lapierreh@agr.gc.ca

\section{INTRODUCTION}

In dairy cows during midlactation, milk protein yield can be manipulated by varying either energy or protein intake (MacRae et al., 2000). In mechanistic terms, however, changes in either energy or protein supply have been shown to exert different effects on wholebody protein metabolism. For example, $\mathrm{CN}$ infusion increased both whole-body protein synthesis and Leu exported in milk to a greater extent than did propionate (C3; Raggio et al., 2006). Furthermore, although wholebody Leu oxidation increased with $\mathrm{CN}$ treatment, the addition of $\mathrm{C} 3$ to the $\mathrm{CN}$ treatment reduced Leu oxidation compared with $\mathrm{CN}$ alone. Whether these different responses at the whole-body level are also reflected in mammary gland (MG) metabolism is unknown, however.

More studies have examined responses in MG protein metabolism to altered AA supply than impacts of changed energy provision. Additional protein, via CN infusion, has been shown to increase milk protein output in a wide range of studies (Hanigan et al., 1998). Furthermore, it is well established that the MG can adjust both protein synthesis and Leu oxidation in response to either a high protein intake (Bequette et al., 1996a) or a deficiency in Leu provision (Bequette et al., 1996b). To date, however, no studies have related the impact of energy supply alone to mammary protein metabolism in dairy cows. Partly this may relate to the relatively moderate responses in milk protein yield observed with either glucose or C3 supplementation (Huhtanen et al., 2002; Rigout et al., 2003). Nonetheless, in view of the known interaction between energy and protein supply in determining milk output, it is clearly necessary to understand the separate and combined effects of these major macronutrients.

In studies in which protein supply has been increased, the uptake:output ratio for the branched-chain AA and Lys is usually elevated (Metcalf et al., 1991; Guinard and Rulquin, 1994; Bequette et al., 1996a; Vanhatalo et al., 2003b; Raggio et al., 2004). This raises the important question of what the fates of this excess AA uptake are. Some reports suggest that these AA 
may be predominantly oxidized (Bequette et al., 1996a) or used to provide $\mathrm{N}$ for synthesis of other AA (Lapierre et al., 2005), or both. It has also been proposed that under certain conditions, the MG may release the excess AA taken up as peptides into the mammary vein (Guinard and Rulquin, 1994; Rulquin et al., 2004). The importance of these alternative fates needs to be resolved to increase our understanding of how the $\mathrm{MG}$ responds to changes in nutrient supply.

Therefore, the objectives of this study were 1) to differentiate how increased milk protein secretion in response to a change in energy and protein supply relates to changes in MG protein metabolism and net uptake of AA, and 2) to quantify, for Leu, the metabolic fate of that taken up in excess relative to milk output. These objectives were achieved by coupling the arterio-venous technique with infusion of labeled (stable isotope) Leu and bicarbonate. Whole-body protein kinetics from this study have been reported previously (Raggio et al., 2006).

\section{MATERIALS AND METHODS}

\section{Animals and Treatments}

Three multiparous Holstein cows, averaging $615 \pm$ $24 \mathrm{~kg}$ of BW and $65 \pm 4 \mathrm{DIM}$ at the beginning of the study, were fitted with both a proximal T-shaped duodenal cannula, placed 10 to $15 \mathrm{~cm}$ from the pylorus, and a ruminal cannula (Hurtaud et al., 1998) before calving. Approximately $20 \mathrm{~d}$ after calving, cows were surgically prepared with an ultrasonic flow probe (Transonic Systems Inc., Ithaca, NY) implanted around the right external pudic artery as previously described (Rigout et al., 2002), and 2 permanent catheters were placed in the right carotid artery and in the right subcutaneous abdominal vein (for a description of catheters see Guinard et al., 1994, and Raggio et al., 2006). During the experiment, problems were encountered with 2 catheters. One arterial catheter failed and a replacement catheter was inserted in the left carotid artery. In another cow the subcutaneous abdominal vein catheter was nonfunctional and a temporary catheter was inserted (for $3 \mathrm{~d}$ ) during the second week of each period. In addition, one ultrasonic flow probe failed after the second period. For the tracer infusions, a catheter was inserted in the left jugular vein for the whole study. Catheter maintenance was performed as described previously (Guinard et al., 1994). The surgical preparations were reviewed and approved by the Animal Care Committee of the French Ministry of Agriculture.

The same basal diet (Raggio et al., 2006) was fed during the whole study, balanced to provide limited intestinal glucose (Rigout et al., 2003). The basal diet was estimated to supply $1,593 \mathrm{~g} / \mathrm{d}$ of protein truly di- gested in the small intestine (PDI) and $124 \mathrm{MJ} / \mathrm{d}$ of $\mathrm{NE}_{\mathrm{L}}$ (INRA, 1989), or $1,624 \mathrm{~g} / \mathrm{d}$ of $\mathrm{MP}$ and $119 \mathrm{MJ} / \mathrm{d}$ of $\mathrm{NE}_{\mathrm{L}}$ (NRC, 2001). The quantity of wet feed offered was adjusted every day to ensure the same delivery of DM on each experimental day, based on an estimation of DM content of the silage. The concentrate was supplied every $3 \mathrm{~h}$ in equal portions from automatic feeders, starting at $0715 \mathrm{~h}$. Grass silage was fed 3 times per day: $25 \%$ at $0715 \mathrm{~h}, 25 \%$ at $1315 \mathrm{~h}$, and $50 \%$ between 1715 and 1915 h. However, to maintain a better steady state, the silage was fed 5 times per day during the kinetic days: $12.5 \%$ at $0715,1015,1315$, and $1615 \mathrm{~h}$ and then $50 \%$ at $1915 \mathrm{~h}$. Throughout the study, access to the diet was limited to $1 \mathrm{~h}$ after the concentrate distribution times. Cows had free access to water and were housed in individual tie stalls. Every day before $0715 \mathrm{~h}$, feed refusals were collected, weighed, and sampled for later analyses.

The infusion of 2 nutrients was tested, separately or in combination, according to a $2 \times 2$ factorial arrangement: duodenal infusion of calcium caseinate $(743 \pm 7$ $\mathrm{g} / \mathrm{d}$, estimated to provide $687 \mathrm{~g} / \mathrm{d}$ of PDI, and $7.9 \mathrm{MJ} / \mathrm{d}$ of $\mathrm{NE}_{\mathrm{L}}$; Guinard et al., 1994) or ruminal infusions of propionic acid (C3; $1,042 \pm 8 \mathrm{~g} / \mathrm{d}$, estimated to provide 15.6 MJ/d of $\mathrm{NE}_{\mathrm{L}}$; INRA, 1989), or both. Therefore, the 4 treatments were 1) control, 2) $\mathrm{CN}, 3$ ) $\mathrm{C} 3$, and 4) $\mathrm{CN}$ and $\mathrm{C} 3$ combined $(\mathbf{C N}+\mathbf{C 3})$. Infusion of $\mathrm{CN}$ increased the PDI balance from $97 \%$ for the control cows to an average of $120 \%$ for the cows receiving $\mathrm{CN}$ infusions. To optimize the effect of $\mathrm{C} 3$, it was infused at the dose that yielded the maximal effect on milk protein observed by Rigout et al. (2003). Each treatment period lasted $14 \mathrm{~d}$, and the first $2 \mathrm{~d}$ of each period served as a transition for the infusions (the cows received, on $d$ $1,33 \%$ of the total subsequent infusion and, on $\mathrm{d} 2$, $66 \%$ of the total subsequent infusion). Preparation of the infusions is detailed in a separate paper (Raggio et al., 2006).

\section{Sampling and Laboratory Analyses}

Cows were milked twice daily ( 0630 and $1830 \mathrm{~h}$ ), with yield recorded at each milking and assayed for fat and true protein composition by infrared analysis (ISO 9622: ISO, 1999, 2000; MilkoScan, Foss Electric, Hillerød, Denmark). During the second week of each treatment period, the udder halves of each cow were milked separately, and the right udder samples were analyzed as described above for composition. Feed samples were taken daily and stored at $-20^{\circ} \mathrm{C}$ until analyzed. Stored samples were pooled by period prior to analysis.

On d 11 of each experimental period, mammary Leu kinetics were determined with a primed $(4.3 \mathrm{mmol})$ continuous infusion of L- $\left[1-{ }^{13} \mathrm{C}\right] \mathrm{Leu}(4.3 \mathrm{mmol} / \mathrm{h}$; Cam- 
bridge Isotope Laboratories, Andover, MA; 99 atom\%) for $7.5 \mathrm{~h}$ (starting at $1000 \mathrm{~h}, 3.5 \mathrm{~h}$ after the morning milking). Cows were made to stand for at least $15 \mathrm{~min}$ before blood sampling. Hourly samples were taken from the carotid artery and mammary vein starting $3 \mathrm{~h}$ after initiation of the infusion $(1300,1400,1500,1600$, and $1700 \mathrm{~h}$ ) and were analyzed to determine the concentration and the isotopic enrichment (IE) of Leu, 4-methyl2-oxopentanoate (MOP), and $\mathrm{CO}_{2}$. In addition, samples for AA and urea concentrations were taken at 0700 , 0900, 1100, 1300, 1500, and $1700 \mathrm{~h}$.

On d 13, a mixture of $\left[{ }^{13} \mathrm{C}\right]$ bicarbonate (Cambridge Isotope Laboratories; 99 atom \%; $4.7 \mathrm{mg} / \mathrm{mL}$ ) and [6.6${ }^{2} \mathrm{H}_{2}$ ]glucose (Cambridge Isotope Laboratories; 99 atom $\% ; 60 \mathrm{mg} / \mathrm{mL}$ ) was infused. The rate of $\left[{ }^{13} \mathrm{C}\right]$ bicarbonate infusion was $4.2 \mathrm{mmol} / \mathrm{h}$ for $4 \mathrm{~h}$ between 1200 and 1600 $\mathrm{h}$, preceded by a priming dose $(3.2 \mathrm{mmol})$. Glucose kinetics will be described in a separate paper. Samples were taken from the carotid artery and mammary vein starting $1.75 \mathrm{~h}$ after initiation of the infusion $(1345,1430$, 1515 , and $1600 \mathrm{~h}$ ) and were analyzed for concentration and IE of $\mathrm{CO}_{2}$. On d 11, samples were also collected from the artery prior to the infusions to determine the natural abundance of Leu and MOP (2 samples). On both days of infusion, 3 samples were taken from the artery and the mammary vein to determine the natural abundance of $\mathrm{CO}_{2}$ because it differs between blood vessels (Read et al., 1984).

Blood samples for AA concentrations were collected in heparinized syringes and kept on ice. Plasma was prepared by centrifugation $\left(2,000 \times g\right.$ at $4^{\circ} \mathrm{C}$ for 15 min). To $0.7 \mathrm{~g}$ of plasma was added $0.4 \mathrm{~g}$ of an internal standard solution, and the mixture was stored at $-80^{\circ} \mathrm{C}$. The internal standard solution was a U- ${ }^{13} \mathrm{C}$ algal hydrolysate plus the following AA: $\left[5-{ }^{15} \mathrm{~N}\right] \mathrm{Gln}(501 \mathrm{nmol} /$ $\mathrm{g})$, [indole- $\left.{ }^{15} \mathrm{~N}\right] \operatorname{Trp}(252 \mathrm{nmol} / \mathrm{g})$, and $\left[1-{ }^{13} \mathrm{C}\right]$ Cys $(260$ $\mathrm{nmol} / \mathrm{g}$ ). The AA concentrations were determined by isotope dilution as previously described (Calder et al., 1999).

For MOP and $\left[1-{ }^{13} \mathrm{C}\right]$ Leu IE (expressed as molar percent excess, mpe) and MOP concentration, $0.7 \mathrm{~g}$ of plasma was weighed and $0.3 \mathrm{~g}$ of an oxohexanoic acid solution $(33.3 \mathrm{nmol} / \mathrm{g})$ was added, and the mixture was stored at $-80^{\circ} \mathrm{C}$ until analysis. Determinations of MOP and Leu IE were as described by Calder and Smith (1988). For $\mathrm{CO}_{2} \mathrm{IE}$, triplicate 1-mL blood samples were injected into evacuated Vacutainers (Becton Dickinson, Plymouth, UK) containing $1 \mathrm{~mL}$ of lactic acid, immediately mixed, and kept at room temperature until analysis. Determination of IE was as previously described (Lobley et al., 2003) based on Read et al. (1984).

\section{Calculations}

In addition to the blood flow probe, mammary plasma flow $(\mathbf{P F})$ was estimated according to the Fick principle, using Phe and Tyr as internal markers with an allowance for a $3.5 \%$ contribution from blood-derived proteins (Linzell, 1974; Cant et al., 1993). For this paper, the Fick principle was adopted to estimate $\mathrm{PF}$ and calculate mammary AA fluxes because the probe was not functional for one cow. For the 2 functional cows, the probe measurements were $24 \%$ lower than mammary PF estimated with the Fick principle. Similar underestimates with ultrasound probes have previously been observed when compared either with the Fick principle (Thivierge et al., 2002) or with $p$-aminohippurate (Bequette et al., 1999). Nevertheless, there was no effect of treatment on the uptake:output ratio of Phe and Tyr when the uptake was estimated with the PF from the probe for the 2 functional cows. Secretions of AA into milk were calculated using published AA concentrations in milk (Swaisgood, 1993) except for Leu, Phe, and Tyr, for which milk samples were acid-hydrolyzed with $6 \mathrm{~N}$ phenol- $\mathrm{HCl}$ for $18 \mathrm{~h}$ at $110^{\circ} \mathrm{C}(\mathrm{AOAC}, 2000)$ and $\mathrm{AA}$ concentrations of the hydrolysates were determined by the isotope dilution method (Calder et al., 1999). Concentrations of Leu, Phe, and Tyr averaged 98, 49, and $52 \mathrm{~g} / \mathrm{kg}$ of $\mathrm{CP}$, respectively.

For the following equations, infusion rates and fluxes of Leu, MOP, or $\mathrm{CO}_{2}$ are in millimoles per hour. The concentrations of Leu, MOP, and $\mathrm{CO}_{2}$ are expressed in millimoles per liter. The IE of ${ }^{13} \mathrm{C}$ Leu, ${ }^{13} \mathrm{C} \mathrm{MOP}$, and ${ }^{13} \mathrm{CO}_{2}$, are given in mpe/100. In all cases, $m$ refers to the mammary vein, and $a$ to the artery. Plasma flow is given in $\mathrm{L} / \mathrm{h}$.

Net Leu uptake was calculated as

$$
\text { net uptake }=([\text { Leu- } a]-[\text { Leu- } m]) \times \text { PF }
$$

using the 6 samples collected every other hour, because milk protein yield over the $12 \mathrm{~h}$ was used to calculate the PF with the Fick principle. Net uptakes measured during infusion of the tracer were corrected for the extra oxidation in the MG caused by infusion of the tracer as described below (CorOx).

Mammary gland Leu kinetics were studied using a 3-compartment model with Leu, $\mathrm{CO}_{2}$, and MOP as previously described by Bequette et al. (2002), but with IE of MOP from the mammary vein taken as representative of IE of the precursor pool.

The MG irreversible loss rate (ILR) of Leu was calculated as follows:

$$
\begin{aligned}
\mathrm{MG} \text { Leu ILR } & =\left[\left\{\left([\mathrm{Leu}-a] \times \mathrm{IE}_{\mathrm{Leu}-a}-[\mathrm{Leu}-m] \mathrm{IE}_{\mathrm{Leu}-m}\right)\right.\right. \\
& \left.\times \mathrm{PF}\} / \mathrm{IE}_{\mathrm{MOP}-m}\right]- \text { CorOx }
\end{aligned}
$$

Dynamic transfers of MOP to Leu or $\mathrm{CO}_{2}$ (positive values) or Leu to MOP (negative values) were calculated from 
$\mathrm{MG}$ MOP to Leu or $\mathrm{CO}_{2}=\left\{\left([\mathrm{MOP}-a] \times \mathrm{IE}_{\mathrm{MOP}-a}\right.\right.$

$$
\left.\left.-[\mathrm{MOP}-m] \times \mathrm{IE}_{\mathrm{MOP}-m}\right) \times \mathrm{PF}\right\} / \mathrm{IE}_{\mathrm{MOP}-m}
$$

where [Leu] and [MOP] refer to concentrations of Leu and MOP, respectively, IE refers to their isotopic enrichment, and $\mathrm{PF}$ refers to plasma flow.

Blood flow was used to calculate $\mathrm{MG}^{13} \mathrm{CO}_{2}$ fluxes and was estimated as follows:

$$
\mathrm{BF}=\mathrm{PF} /(1-\text { hematocrit- } a)
$$

where $\mathrm{BF}$ is blood flow. The $\mathrm{MG}{ }^{13} \mathrm{CO}_{2}$ flow was calculated as follows:

$$
\begin{aligned}
\mathrm{MG}{ }^{13} \mathrm{CO}_{2}= & \left(\left[\mathrm{CO}_{2}-m\right] \times \mathrm{IE}^{13} \mathrm{CO}_{2}-m-\left[\mathrm{CO}_{2}-a\right]\right. \\
& \left.\times \mathrm{IE}^{13} \mathrm{CO}_{2}-a\right) \times \mathrm{BF}
\end{aligned}
$$

To correct for ${ }^{13} \mathrm{CO}_{2}$ sequestration (Sq) that occurred during the infusion of ${ }^{13} \mathrm{C} \mathrm{Leu,}{ }^{13} \mathrm{CO}_{2}$ Sq was estimated during the bicarbonate infusion as the arterial inflow of ${ }^{13} \mathrm{CO}_{2}$ not recovered in the mammary vein. During period 6, Sq was not determined because of technical problems with the measurements of $\mathrm{IE}$ of ${ }^{13} \mathrm{CO}_{2}$ during the bicarbonate infusion. We used an average of Sq for each cow $(1.4,1.2$, and $4.8 \%)$ because no significant differences were observed between treatments.

Therefore, the corrected $\mathrm{MG}{ }^{13} \mathrm{CO}_{2}$ flux was calculated as follows:

$$
\begin{aligned}
\mathrm{MG}{ }^{13} \mathrm{CO}_{2} \text { corrected } & =\left(\text { arterial inflow of }{ }^{13} \mathrm{CO}_{2} \times \mathrm{Sq}\right) \\
& +\mathrm{MG}^{13} \mathrm{CO}_{2}
\end{aligned}
$$

Oxidation of Leu (Leu Ox) across the MG was calculated as

$$
\text { MG Leu Ox }=\mathrm{MG}^{13} \mathrm{CO}_{2} \text { corrected/IE } \mathrm{E}_{\mathrm{MOP}-m}-\mathrm{CorOx}
$$

Tracer kinetics assumes the animal does not distinguish between ${ }^{13} \mathrm{C}-\mathrm{AA}$ and ${ }^{12} \mathrm{C}-\mathrm{AA}$. In addition, at the whole-body level, it was assumed that all Leu tracer infused was in excess, and that a corresponding amount of Leu was thus oxidized by the animal (Raggio et al., 2006). Accordingly, it was assumed that mammary Leu oxidation measured during the tracer infusion included a proportion of this extra oxidation, calculated to be in proportion to the measured MG oxidation as a fraction of the measured whole-body oxidation (before correction was made to account for the tracer infusion) multiplied by the infusion rate. This factor (CorOx) was subtracted from the measured Leu oxidation across the MG as well as the ILR and net flux, which should have all been increased by this amount during the tracer infusion.
Fractional oxidation was calculated as this corrected oxidation divided by the ILR.

Leucine used for MG protein synthesis was calculated as the difference between the MG Leu ILR, including conversion to or from MOP, and MG oxidation. Once Leu used for milk protein secretion was subtracted from Leu used for protein synthesis, the remainder was converted into kilograms of constitutive protein, applying the factor $63 \mathrm{~g}$ of Leu/kg of constitutive protein (Lobley et al., 1980).

"Residual" Leu was obtained by the difference of the amount of Leu taken up by the MG plus the dynamic transfer of MOP to Leu or $\mathrm{CO}_{2}$ minus oxidation and secretion as milk protein. This represents the net mammary Leu inflow not accounted for by the measured outflows:

$$
\begin{gathered}
\text { residual }=\text { net Leu uptake }+ \text { MOP to Leu or } \mathrm{CO}_{2} \\
- \text { MG Ox }- \text { Leu in milk }
\end{gathered}
$$

If positive and significantly different from zero, this "residual" would suggest that an additional metabolic fate occurred (e.g., release in peptide form into the mammary vein).

Net mammary uptake of other AA was calculated using the 6 samples collected every other hour as follows:

$$
\text { net uptake }=([\mathrm{AA}-a]-[\mathrm{AA}-m]) \times \mathrm{PF}
$$

where $[\mathrm{AA}]$ refers to concentrations of individual AA and $\mathrm{PF}$ refers to plasma flow.

\section{Experimental Design and Statistical Analyses}

The original design was a $4 \times 4$ Latin square, but the loss of one cow before the start of the experiment led to a redesign of the experiment as 2 incomplete $4 \times 3$ Youden squares, with 3 periods for each square (i.e., 6 periods per cow), for a total of 18 observations distributed as follows: control, $\mathrm{n}=5 ; \mathrm{CN}, \mathrm{n}=4 ; \mathrm{C} 3, \mathrm{n}=5 ; \mathrm{CN}$ $+\mathrm{C} 3, \mathrm{n}=4$. During the third period, one cow had a problem with her catheter during the $\mathrm{CN}$ treatment, and as a consequence, $\mathrm{n}=3$ for $\mathrm{CN}$.

Analyses of variance were made using the MIXED procedure of SAS (SAS Institute, 1999) according to the following statistical model:

$$
\begin{gathered}
\mathrm{y}_{\mathrm{ijkl}}=\mu+\operatorname{SQUARE}_{\mathrm{i}}+\operatorname{PERIOD}_{\mathrm{j}}\left(\mathrm{SQUARE}_{\mathrm{i}}\right) \\
+\mathrm{COW}_{\mathrm{k}}+\mathrm{TREAT}_{1}+\mathrm{e}_{\mathrm{iikl}}
\end{gathered}
$$

Differences among treatments were compared using orthogonal contrasts, estimating the main effect of $\mathrm{CN}$, 
Table 1. Effect of $\mathrm{CN}$ and propionate (C3) supply on milk yield and composition of the right-half udder in dairy cows ${ }^{1}$

\begin{tabular}{|c|c|c|c|c|c|c|c|c|}
\hline \multirow[b]{2}{*}{ Item } & \multicolumn{4}{|c|}{ Treatment } & \multirow[b]{2}{*}{ SEM } & \multicolumn{3}{|c|}{$P$} \\
\hline & Control & $\mathrm{CN}$ & C3 & $\mathrm{CN}+\mathrm{C} 3$ & & $\mathrm{CN}$ & C3 & $\mathrm{CN} \times \mathrm{C} 3$ \\
\hline Milk, kg/12 h & 6.38 & 7.39 & 6.55 & 7.38 & 0.19 & $<0.001$ & 0.68 & 0.60 \\
\hline True protein, g/kg & 29.3 & 30.2 & 30.6 & 32.8 & 0.8 & 0.04 & 0.03 & 0.35 \\
\hline True protein, g/12 h & 186 & 222 & 197 & 240 & 7 & $<0.01$ & 0.06 & 0.59 \\
\hline $\mathrm{CN}, \%$ of true protein & 82.4 & 83.5 & 82.0 & 82.3 & 0.4 & 0.07 & 0.05 & 0.31 \\
\hline $\mathrm{NPN}, \%$ of $\mathrm{CP}$ & 2.13 & 2.39 & 2.05 & 2.24 & 0.09 & 0.02 & $<0.01$ & 0.17 \\
\hline Fat, $\mathrm{g} / \mathrm{kg}$ & 44.8 & 42.3 & 46.1 & 39.0 & 2.7 & 0.07 & 0.71 & 0.36 \\
\hline Fat, g/12 h & 282 & 304 & 299 & 286 & 24 & 0.82 & 0.97 & 0.40 \\
\hline
\end{tabular}

${ }^{1}$ Least squares means presented with pooled SEM, given for $\mathrm{n}=3$; from the half udder in the evening $(12 \mathrm{~h})$ of the Leu kinetic day ( 17 observations: control $=5, \mathrm{CN}=3, \mathrm{C} 3=5, \mathrm{CN}+\mathrm{C} 3=4)$. $P=$ probability corresponding to the null hypothesis with $\mathrm{CN}, \mathrm{C} 3$, and $\mathrm{CN} \times \mathrm{C} 3$ contrasts.

C3, and the interaction between the 2 nutrients. Results are expressed as least square means with the highest standard error of the mean. Significance was set at $P$ $\leq 0.05$ and the tendency at $0.05 \leq P \leq 0.10$.

\section{RESULTS}

Milk production and composition for the last week of the experimental periods were presented in a previous paper (Raggio et al., 2006). In the present paper, milk production and composition were based on the righthalf udder at the evening milking ( $12 \mathrm{~h}$ ) of the Leu kinetic day (Table 1). Milk yield increased with $\mathrm{CN}$ treatments $(P<0.001)$. True protein concentration and yield both increased with $\mathrm{CN}(P=0.04 ; P<0.01)$ and C3 $(P=0.03 ; P=0.06)$ infusions.

\section{Mammary Leu Kinetics}

The mammary PF tended to decrease by an average of $16 \%$ ( $P=0.07)$ when $\mathrm{CN}$ was infused and increased by $32 \%(P=0.02)$ when $\mathrm{C} 3$ was supplied (Table 2$)$. The MG Leu kinetics are presented in Table 2. The net uptake of Leu and MOP increased with CN infusions $(P<0.01)$ but did not show an effect when $\mathrm{C} 3$ was infused. The MG Leu ILR was increased by CN infusions $(P<0.001)$ and tended to increase with $\mathrm{C} 3$ treatments $(P=0.09)$. In addition, there was a $\mathrm{CN} \times \mathrm{C} 3$ interaction $(P<0.01)$, because the response with combined treatments was smaller than the sum of the response to each nutrient supplied separately. Both dynamic transfer of MOP to Leu or $\mathrm{CO}_{2}$ (MOP to Leu or $\mathrm{CO}_{2}$ ) and mammary oxidation of Leu ( $\mathrm{Leu} \mathrm{Ox}$ ) increased when $\mathrm{CN}$ was supplied $(P=0.04 ; P<0.001$, respectively). The mammary fractional oxidation of Leu increased $(P<0.001)$ with CN supply. Leucine used for protein synthesis (Leu PS) increased with $\mathrm{CN}(P=0.02)$ but, as with the ILR, there was a tendency for a $\mathrm{CN} \times$ C3 interaction $(P=0.09)$. Leucine in milk protein (Leu
Milk) increased with $\mathrm{CN}$ treatments $(P<0.001)$ and tended to increase with $\mathrm{C} 3$ infusions $(P=0.06)$. In addition, differences were observed for Leu derived from protein degradation (estimated as Leu PS minus Leu Milk), with an increase with $\mathrm{CN}$ alone compared with the control, but a decrease with $\mathrm{CN}$ and $\mathrm{C} 3$ combined compared with $\mathrm{C} 3$ (interaction $\mathrm{CN} \times \mathrm{C} 3, P<0.001$ ).

\section{AA Arterio-Venous Concentration Differences}

The AA arterio-venous concentration differences are presented in Table 3 . When $\mathrm{CN}$ was supplied, the arterio-venous difference increased for all AA $(P \leq 0.05)$, except for Asp and Glu, for which there was no effect, and for Ala, for which there was a decrease $(P=0.03)$. In contrast, during $\mathrm{C} 3$ infusions the arterio-venous differences decreased for all AA $(P \leq 0.06)$ except Asp, Cys, Glu, Ser, and Thr, which were not affected, and Ala, for which there was an increase $(P<0.01)$. There was also a trend $(P \leq 0.10)$ for an interaction with the branched-chain AA, with a larger decrease with $\mathrm{C} 3$ and $\mathrm{CN}$ compared with $\mathrm{CN}$ than when comparing $\mathrm{C} 3$ with the control.

\section{AA Uptake and Uptake:Output Ratio}

The MG uptake data are presented in Table 4. During $\mathrm{CN}$ infusions, the uptake increased $(P \leq 0.01)$ for all the essential AA (EAA) as well as for Gln, Gly, and Pro, whereas uptakes were reduced for Ala $(P<0.001)$ and Glu $(P=0.02)$. With C3 treatments, uptake of the nonessential AA (NEAA) Ala, Glu, and Pro, as well as the EAA Met, Phe, and Thr, increased $(P<0.05)$. There was also a $\mathrm{CN} \times \mathrm{C} 3$ interaction $(P=0.02)$ for Ala uptake, with a larger decrease when $\mathrm{CN}$ was added to the control diet than when $\mathrm{CN}$ was added to $\mathrm{C} 3$.

The AA uptake:output ratios are presented in Table 5 . If the ratio exceeded unity, then the mammary uptake was more than sufficient to account for milk pro- 
Table 2. Effect of CN and propionate (C3) supply on Leu kinetics and plasma flow of the right-half udder in dairy cows ${ }^{1}$

\begin{tabular}{|c|c|c|c|c|c|c|c|c|}
\hline \multirow{2}{*}{$\begin{array}{l}\text { Item, } \\
\mathrm{mmol} / \mathrm{h}\end{array}$} & \multicolumn{4}{|c|}{ Treatment } & \multirow[b]{2}{*}{ SEM } & \multicolumn{3}{|c|}{$P$} \\
\hline & Control & $\mathrm{CN}$ & C3 & $\mathrm{CN}+\mathrm{C} 3$ & & $\mathrm{CN}$ & C3 & $\mathrm{CN} \times \mathrm{C} 3$ \\
\hline Net Leu ${ }^{2}$ & 13.48 & 17.63 & 14.11 & 18.37 & 0.83 & $<0.001$ & 0.40 & 0.94 \\
\hline Net $\mathrm{MOP}^{3}$ & 0.22 & 0.37 & 0.19 & 0.29 & 0.03 & $<0.01$ & 0.19 & 0.39 \\
\hline Leu ILR ${ }^{4}$ & 18.65 & 24.48 & 21.07 & 23.97 & 0.51 & $<0.001$ & 0.09 & 0.01 \\
\hline MOP to Leu or $\mathrm{CO}_{2}$ & 0.13 & 0.29 & 0.16 & 0.25 & 0.06 & 0.04 & 0.84 & 0.45 \\
\hline Leu $\mathrm{Ox}^{5}$ & 1.52 & 4.28 & 1.69 & 4.04 & 0.38 & $<0.001$ & 0.90 & 0.54 \\
\hline Fractional Ox & 0.08 & 0.18 & 0.08 & 0.16 & 0.01 & $<0.001$ & 0.55 & 0.54 \\
\hline Leu $\mathrm{PS}^{6}$ & 17.25 & 20.49 & 19.54 & 20.18 & 0.76 & 0.02 & 0.21 & 0.09 \\
\hline Leu Residual ${ }^{7}$ & 0.44 & -0.28 & 0.20 & -0.42 & 0.76 & 0.30 & 0.81 & 0.95 \\
\hline Leu Milk ${ }^{8}$ & 11.64 & 13.93 & 12.34 & 15.01 & 0.43 & $<0.001$ & 0.06 & 0.61 \\
\hline Leu Milk/Leu PS & 0.75 & 0.77 & 0.71 & 0.83 & 0.01 & $<0.001$ & 0.62 & 0.02 \\
\hline Leu PS - Leu Milk & 4.54 & 4.99 & 6.02 & 3.62 & 0.33 & $<0.01$ & 0.85 & $<0.001$ \\
\hline MG Leu Ox/WB Leu $\mathrm{Ox}^{9}$ & 0.49 & 0.43 & 0.4 & 0.47 & 0.11 & 0.98 & 0.85 & 0.49 \\
\hline MG ILR/WB ILR ${ }^{10}$ & 0.42 & 0.43 & 0.43 & 0.38 & 0.02 & 0.22 & 0.40 & 0.10 \\
\hline Plasma flow, L/h & 307 & 241 & 386 & 338 & 32 & 0.07 & 0.02 & 0.75 \\
\hline
\end{tabular}

${ }^{1}$ Least squares means presented with pooled SEM, given for $\mathrm{n}=3(17$ observations: control $=5, \mathrm{CN}=3$, $\mathrm{C} 3=5, \mathrm{CN}+\mathrm{C} 3=4) \cdot P=$ probability corresponding to the null hypothesis with $\mathrm{CN}, \mathrm{C} 3$, and $\mathrm{CN} \times \mathrm{C} 3$ contrasts.

${ }^{2}$ Based on the 6 samples collected every other hour, corrected for increased oxidation due to tracer infusion.

${ }^{3}$ Net 4-methyl-2-oxopentanoate (MOP) uptake during Leu kinetic measurement.

${ }^{4}$ Leucine irreversible loss rate (ILR), corrected for increased oxidation due to tracer infusion.

${ }^{5}$ Leucine oxidation $(\mathrm{Ox})$, corrected for increased oxidation due to tracer infusion.

${ }^{6}$ Leucine used for protein synthesis (PS).

${ }^{7}$ Calculated as net Leu + MOP to Leu or $\mathrm{CO}_{2}$ - Leu Ox - Leu Milk.

${ }^{8} \mathrm{Leu}$ in milk protein, from milk collected from the right-half udder at the evening milking on the day of kinetic measurements.

${ }^{9}$ Mammary gland (MG) oxidation (half udder $\times 2$ )/whole-body (WB) oxidation, adjusted to use the same precursor pool.

${ }^{10}$ Mammary gland ILR (half udder $\times 2$ )/WB ILR, adjusted to use the same precursor pool.

tein secretion; if smaller than unity, then there was a need for either de novo synthesis in the gland or uptake in peptide form. Uptake of EAA was sufficient to account for milk output, except for Met when CN was infused. The uptake:output ratio of NEAA varied greatly between AA, from a large excess for Arg to ratios as low as 0.14 for Asp. With CN treatments, the uptake:output ratios decreased $(P<0.001)$ for Ala and Glu, whereas they increased for Pro $(P<0.001)$, with a tendency to increase $(P \leq 0.08)$ for Ile and Leu. However, when $\mathrm{C} 3$ was supplied, the ratio for Ala increased $(P<$ $0.001)$ and tended to either increase $(P=0.07)$ for Glu or decrease $(P=0.08)$ for Gln.

\section{Nitrogen Balance Across the MG}

Nitrogen balances are presented in Table 6. This calculation is based on mammary uptake and milk output of AA used for protein synthesis, except for Asn, which was not measured. Total $\mathrm{N}$ uptake increased $(P<0.01)$ when $\mathrm{CN}$ was supplied $(P<0.01)$, with a tendency to increase when C3 was infused $(P=0.07)$. Nitrogen uptake as EAA (EAA-N) increased $(P<0.001)$ with CN but C3 had no effect. Nitrogen uptake as NEAA (NEAA-
N) was increased by both $\mathrm{CN}(P=0.05)$ and $\mathrm{C} 3(P=$ 0.03). Total-N, EAA-N, and NEAA-N in milk were all increased for $\mathrm{CN}(P<0.001)$ and tended to increase for $\mathrm{C} 3(P=0.07)$. In terms of $\mathrm{N}$ balances across the $\mathrm{MG}$, the NEAA-N deficit increased $(P=0.05)$ when $\mathrm{CN}$ was infused. Overall, however, uptake of total AA-N from the plasma matched the $\mathrm{N}$ output as milk proteins (Table 6 ), with the small positive values not being significantly different from zero except for a tendency $(P=$ 0.08 ) for the C3 infusion alone.

\section{DISCUSSION}

This study had 2 objectives. The first was to examine whether supplemental protein and energy, the latter as $\mathrm{C} 3$, had similar mechanistic effects on protein and AA metabolism within the MG to increase milk protein yield. The second was to ascertain the fate of excess AA taken up by the MG and help resolve the issue of whether the MG can produce a net secretion of peptides or whether oxidative pathways are the major routes of removal. In both cases, clear answers to these questions were obtained. 
Table 3. Effect of CN and propionate (C3) supply on plasma arterio-venous differences of AA on the righthalf udder in dairy cows ${ }^{1}$

\begin{tabular}{|c|c|c|c|c|c|c|c|c|}
\hline \multirow{2}{*}{$\begin{array}{l}\mathrm{AA} \\
\mu M\end{array}$} & \multicolumn{4}{|c|}{ Treatment } & \multirow[b]{2}{*}{ SEM } & \multicolumn{3}{|c|}{$P$} \\
\hline & Control & $\mathrm{CN}$ & C3 & $\mathrm{CN}+\mathrm{C} 3$ & & $\mathrm{CN}$ & C3 & $\mathrm{CN} \times \mathrm{C} 3$ \\
\hline Ala & 28.5 & 16.5 & 33.4 & 33.1 & 2.64 & 0.03 & $<0.01$ & 0.39 \\
\hline Arg & 24.5 & 32.4 & 22.3 & 27.8 & 1.34 & $<0.01$ & 0.03 & 0.32 \\
\hline Asp & 1.8 & 2.5 & 2.3 & 2.5 & 0.40 & 0.27 & 0.54 & 0.63 \\
\hline Cys & 2.4 & 3.4 & 2.2 & 2.9 & 0.30 & 0.01 & 0.25 & 0.73 \\
\hline Gln & 36.2 & 54.2 & 26.1 & 40.2 & 4.27 & $<0.01$ & 0.02 & 0.60 \\
\hline Glu & 39.5 & 36.5 & 40.6 & 36.9 & 2.61 & 0.17 & 0.74 & 0.88 \\
\hline Gly & -3.9 & 4.2 & -5.4 & 0.1 & 1.62 & $<0.01$ & 0.10 & 0.37 \\
\hline Pro & 9.3 & 20.4 & 8.3 & 18.0 & 0.79 & $<0.01$ & 0.05 & 0.33 \\
\hline Ser & 6.9 & 15.2 & 7.4 & 11.7 & 3.14 & 0.05 & 0.61 & 0.49 \\
\hline Tyr & 14.5 & 21.6 & 11.7 & 16.7 & 1.78 & $<0.001$ & 0.06 & 0.50 \\
\hline His & 9.5 & 13.5 & 8.2 & 11.3 & 0.75 & $<0.01$ & 0.04 & 0.49 \\
\hline Ile & 29.9 & 47.6 & 25.2 & 37.6 & 1.60 & $<0.001$ & $<0.01$ & 0.10 \\
\hline Leu & 45.6 & 73.1 & 38.4 & 58.1 & 2.60 & $<0.001$ & $<0.01$ & 0.12 \\
\hline Lys & 37.7 & 56.9 & 32.2 & 48.2 & 3.00 & $<0.001$ & 0.04 & 0.55 \\
\hline Met & 9.7 & 13.4 & 8.1 & 11.2 & 0.78 & $<0.001$ & 0.04 & 0.65 \\
\hline Phe & 15.6 & 22.4 & 13.8 & 19.3 & 1.07 & $<0.01$ & 0.04 & 0.47 \\
\hline Thr & 19.6 & 27.1 & 17.3 & 23.6 & 0.00 & $<0.01$ & 0.15 & 0.71 \\
\hline $\operatorname{Trp}$ & 3.4 & 5.8 & 3.2 & 4.4 & 0.32 & $<0.01$ & 0.01 & 0.18 \\
\hline Val & 37.1 & 57.4 & 30.5 & 44.5 & 1.73 & $<0.001$ & $<0.001$ & 0.07 \\
\hline
\end{tabular}

${ }^{1}$ Least squares means presented with pooled SEM, given for $\mathrm{n}=3(17$ observations: control $=5, \mathrm{CN}=3$, $\mathrm{C} 3=5, \mathrm{CN}+\mathrm{C} 3=4) \cdot P=$ probability corresponding to the null hypothesis with $\mathrm{CN}, \mathrm{C} 3$, and $\mathrm{CN} \times \mathrm{C} 3$ contrasts.

\section{Protein Metabolism}

Leu Net Uptake. There were obvious differences in how the net uptake of Leu and secretion as milk were affected by the supply of $\mathrm{CN}$ and C3. With CN treatments, the increment in net uptake of Leu was greater than the increase in milk protein yield, with only 59\% of the increment in net uptake transferred to milk. This result supports earlier observations that the difference between mammary net uptake of Leu and secretion in milk protein becomes greater with an increased protein supply. [For example, in terms of the uptake:output ratio, this increased from 1.04 to 1.87 with $\mathrm{CN}$ infusion (Guinard and Rulquin, 1994); from 1.05 to 1.66 with Leu infusion (Rulquin and Pisulewski, 2000); and from 1.10 to 1.40 with a high-RUP supplement (Raggio et al., 2004).] This indicates that metabolic pathways other than milk protein synthesis are stimulated by the protein supply and that these can be determined using tracer infusion, as discussed below.

In contrast, when $\mathrm{C} 3$ was infused, the nonsignificant increase in Leu net uptake (4.4\%) was less than the extra Leu secreted in milk protein. In consequence, the apparent efficiency of use of the extra uptake was $130 \%$. Similarly, Vanhatalo et al. (2003a) did not observe an increase in the uptake of Leu, although milk protein yield was improved by the infusion of glucose. Together, these data suggest that when an increased energy supply elevates the milk protein yield, without any concomitant increase in the protein supply, the MG uses its Leu uptake more efficiently toward milk protein secretion.
However, energy does not always exert a positive effect, because when a very high dose of glucose was infused as an energy substitute, the uptake:output ratio of Leu increased because of a combined decrease in the milk protein yield coupled with an increased Leu net uptake (Rulquin et al., 2004).

Leu Kinetics. The current kinetic data were quantified assuming that the enrichment of MOP in the mammary venous plasma was similar to that of the precursor intracellular pool. Because MOP is formed intracellularly from Leu deamination, MOP release into the venous drainage ideally should reflect intracellular enrichment of Leu. In practice, only part of the venous metabolite is derived from MG intracellular outflow while the rest arises from the bypass arterial supply (Biolo et al., 1995), so the IE of venous MOP will be lower than MOP or Leu in the cells of the MG. Indeed, the intracellular Leu enrichment will lie between those of MOP and Leu in the venous plasma. Consequently, use of venous MOP enrichment as a precursor will slightly overestimate the true rates of protein synthesis but will still allow comparison between treatments.

Compared with the control, $\mathrm{CN}$ alone increased the MG ILR by $22 \%$, confirming the general response observed previously by Bequette et al. (1996a) in dairy cows with increased dietary protein supply. For the current cows, the dynamic increase $(5.8 \mathrm{mmol} / \mathrm{h})$ was partitioned approximately equally between oxidation and protein synthesis, of which $80 \%$ went to exported proteins (milk) and the rest to constitutive sources. 
Table 4. Effect of $\mathrm{CN}$ and propionate (C3) supply on AA uptake by the right-half udder in dairy cows ${ }^{1}$

\begin{tabular}{|c|c|c|c|c|c|c|c|c|}
\hline \multirow{2}{*}{$\begin{array}{l}\mathrm{AA}, \\
\mathrm{mmol} / \mathrm{h}\end{array}$} & \multicolumn{4}{|c|}{ Treatment } & \multirow[b]{2}{*}{ SEM } & \multicolumn{3}{|c|}{$P$} \\
\hline & Control & $\mathrm{CN}$ & C3 & $\mathrm{CN}+\mathrm{C} 3$ & & $\mathrm{CN}$ & C3 & $\mathrm{CN} \times \mathrm{C} 3$ \\
\hline Ala & 8.8 & 3.6 & 12.8 & 10.9 & 0.64 & $<0.001$ & $<0.001$ & 0.02 \\
\hline Arg & 7.4 & 8.1 & 8.5 & 9.3 & 0.83 & 0.33 & 0.18 & 0.94 \\
\hline Asp & 0.5 & 0.6 & 0.9 & 0.8 & 0.18 & 0.99 & 0.13 & 0.71 \\
\hline Cys & 0.7 & 0.8 & 0.8 & 0.9 & 0.09 & 0.11 & 0.24 & 0.66 \\
\hline Gln & 11.1 & 13.7 & 9.8 & 13.2 & 0.66 & $<0.001$ & 0.21 & 0.52 \\
\hline Glu & 12.1 & 8.9 & 15.6 & 12.2 & 1.29 & 0.02 & 0.03 & 0.95 \\
\hline Gly & -1.3 & 1.0 & -2.4 & 0.0 & 0.51 & $<0.01$ & 0.07 & 0.99 \\
\hline Pro & 2.7 & 5.1 & 3.2 & 5.8 & 0.23 & $<0.001$ & 0.02 & 0.45 \\
\hline Ser & 2.0 & 3.6 & 2.6 & 3.8 & 0.89 & 0.11 & 0.67 & 0.76 \\
\hline Tyr & 4.4 & 5.4 & 4.4 & 5.4 & 0.25 & $<0.01$ & 0.89 & 0.98 \\
\hline His & 2.9 & 3.3 & 3.1 & 3.7 & 0.17 & 0.01 & 0.12 & 0.69 \\
\hline Ile & 9.1 & 11.9 & 9.5 & 12.4 & 0.57 & $<0.001$ & 0.34 & 0.93 \\
\hline $\mathrm{Leu}^{2}$ & 13.5 & 17.6 & 14.1 & 18.4 & 0.83 & $<0.001$ & 0.40 & 0.94 \\
\hline Lys & 11.4 & 14.1 & 12.3 & 15.9 & 0.84 & $<0.001$ & 0.14 & 0.51 \\
\hline Met & 2.9 & 3.3 & 3.1 & 3.7 & 0.10 & $<0.001$ & 0.05 & 0.26 \\
\hline Phe & 4.7 & 5.5 & 5.2 & 6.3 & 0.20 & $<0.01$ & 0.01 & 0.43 \\
\hline Thr & 5.9 & 6.7 & 6.5 & 7.8 & 0.37 & 0.01 & 0.05 & 0.52 \\
\hline Trp & 1.2 & 1.5 & 1.2 & 1.4 & 0.09 & 0.01 & 0.92 & 0.64 \\
\hline Val & 11.2 & 14.3 & 11.5 & 14.7 & 0.69 & $<0.01$ & 0.59 & 0.94 \\
\hline
\end{tabular}

${ }^{1}$ Least squares means presented with pooled SEM, given for $\mathrm{n}=3(17$ observations: control $=5, \mathrm{CN}=3$, $\mathrm{C} 3=5, \mathrm{CN}+\mathrm{C} 3=4) . P=$ probability corresponding to the null hypothesis with $\mathrm{CN}, \mathrm{C} 3$, and $\mathrm{CN} \times \mathrm{C} 3$ contrasts.

${ }^{2}$ Corrected for increased oxidation due to tracer infusion.

In contrast, with C3 infusions all of the ILR increase $(0.96 \mathrm{mmol} / \mathrm{h})$ was diverted to protein synthesis with a minor effect on oxidation $(0.04 \mathrm{mmol} / \mathrm{h})$. This indicates that the MG adjusts differently to increased protein vs. energy supply. Although energy supply is known to influence plasma insulin concentrations, these were unaltered in the current study (unpublished data); thus, other mechanisms must operate. Because energy appears to induce different responses than protein, the possibility thus arises of additive, or even synergistic, effects when both nutrients are supplied together. In practice, however, the interaction between $\mathrm{CN}$ and $\mathrm{C} 3$ on protein synthesis indicates that the cosupply of $\mathrm{CN}$ and C3 was not completely additive.

Table 5. Effect of CN and propionate (C3) supply on AA uptake:milk output ratio in dairy cows ${ }^{1}$

\begin{tabular}{|c|c|c|c|c|c|c|c|c|}
\hline \multirow[b]{2}{*}{$\mathrm{AA}^{2}$} & \multicolumn{4}{|c|}{ Treatment } & \multirow[b]{2}{*}{ SEM } & \multicolumn{3}{|c|}{$P$} \\
\hline & Control & $\mathrm{CN}$ & C3 & $\mathrm{CN}+\mathrm{C} 3$ & & $\mathrm{CN}$ & C3 & $\mathrm{CN} \times \mathrm{C} 3$ \\
\hline $\mathrm{Ala}$ & 1.05 & 0.50 & 2.08 & 1.46 & 0.09 & $<0.001$ & $<0.001$ & 0.06 \\
\hline Arg & 2.44 & 2.23 & 2.64 & 2.33 & 0.24 & 0.23 & 0.53 & 0.83 \\
\hline Asp & 0.14 & 0.12 & 0.21 & 0.16 & 0.04 & 0.39 & 0.23 & 0.61 \\
\hline Cys & 0.80 & 0.78 & 0.83 & 0.83 & 0.07 & 0.86 & 0.63 & 0.84 \\
\hline Gln & 1.09 & 1.14 & 0.92 & 1.02 & 0.07 & 0.30 & 0.08 & 0.67 \\
\hline Glu & 0.93 & 0.58 & 1.14 & 0.74 & 0.09 & $<0.001$ & 0.07 & 0.73 \\
\hline Pro & 0.20 & 0.31 & 0.22 & 0.33 & 0.01 & $<0.001$ & 0.16 & 0.93 \\
\hline Ser & 0.21 & 0.32 & 0.26 & 0.30 & 0.08 & 0.30 & 0.89 & 0.70 \\
\hline His & 1.06 & 1.02 & 1.08 & 1.06 & 0.05 & 0.50 & 0.64 & 0.91 \\
\hline Ile & 1.29 & 1.41 & 1.28 & 1.37 & 0.05 & 0.07 & 0.61 & 0.76 \\
\hline Leu & 1.16 & 1.27 & 1.14 & 1.22 & 0.05 & 0.08 & 0.50 & 0.76 \\
\hline Lys & 1.29 & 1.33 & 1.30 & 1.40 & 0.07 & 0.29 & 0.51 & 0.59 \\
\hline Met & 1.00 & 0.95 & 0.99 & 0.97 & 0.02 & 0.09 & 0.94 & 0.42 \\
\hline Thr & 1.05 & 0.99 & 1.09 & 1.06 & 0.04 & 0.27 & 0.26 & 0.72 \\
\hline Trp & 1.02 & 1.07 & 1.00 & 0.97 & 0.07 & 0.88 & 0.43 & 0.52 \\
\hline Val & 1.28 & 1.36 & 1.24 & 1.29 & 0.06 & 0.23 & 0.36 & 0.78 \\
\hline
\end{tabular}

${ }^{1}$ Least squares means presented with pooled SEM, given for $\mathrm{n}=3$; milk output was estimated from milk collected from the half udder on the evening of the Leu kinetic day $(17$ observations: control $=5, \mathrm{CN}=3$, $\mathrm{C} 3=5, \mathrm{CN}+\mathrm{C} 3=4) . P=$ probability corresponding to the null hypothesis with $\mathrm{CN}, \mathrm{C} 3$, and $\mathrm{CN} \times \mathrm{C} 3$ contrasts.

${ }^{2}$ Phe and Tyr were not included because they were used to calculated plasma flow. 
Table 6. Effect of $\mathrm{CN}$ and propionate (C3) supply on the nitrogen balance in the right-half udder in dairy cows $^{1}$

\begin{tabular}{|c|c|c|c|c|c|c|c|c|}
\hline \multirow{2}{*}{$\begin{array}{l}\text { Nitrogen, } \\
\mathrm{mmol} / \mathrm{h}\end{array}$} & \multicolumn{4}{|c|}{ Treatment } & \multirow[b]{2}{*}{ SEM } & \multicolumn{3}{|c|}{$P$} \\
\hline & Control & $\mathrm{CN}$ & C3 & $\mathrm{CN}+\mathrm{C} 3$ & & $\mathrm{CN}$ & C3 & $\mathrm{CN} \times \mathrm{C} 3$ \\
\hline \multicolumn{9}{|l|}{ Uptake } \\
\hline Total-N & 163.0 & 189.5 & 178.0 & 212.8 & 9.43 & 0.01 & 0.07 & 0.62 \\
\hline EAA-N & 81.3 & 100.7 & 86.4 & 109.2 & 4.89 & $<0.001$ & 0.18 & 0.69 \\
\hline NEAA-N & 81.7 & 88.8 & 91.7 & 103.6 & 4.81 & 0.05 & 0.03 & 0.57 \\
\hline Group 1 & 23.0 & 27.0 & 24.5 & 29.5 & 0.88 & 0.00 & 0.05 & 0.54 \\
\hline Group 2 & 56.7 & 72.1 & 59.7 & 77.4 & 3.70 & 0.00 & 0.26 & 0.73 \\
\hline Group 3 & 79.6 & 86.4 & 89.7 & 101.1 & 4.98 & 0.09 & 0.03 & 0.59 \\
\hline \multicolumn{9}{|l|}{ Milk } \\
\hline Total-N & 156.1 & 186.8 & 165.2 & 200.9 & 5.74 & $<0.001$ & 0.07 & 0.61 \\
\hline EAA-N & 68.9 & 82.6 & 73.0 & 88.8 & 2.54 & $<0.001$ & 0.07 & 0.61 \\
\hline NEAA-N & 87.1 & 104.3 & 92.2 & 112.2 & 3.20 & $<0.001$ & 0.07 & 0.61 \\
\hline Group 1 & 22.5 & 26.9 & 23.9 & 29.0 & 0.83 & $<0.001$ & 0.07 & 0.61 \\
\hline Group 2 & 45.3 & 54.2 & 47.9 & 58.3 & 1.67 & $<0.001$ & 0.07 & 0.61 \\
\hline Group 3 & 84.9 & 101.7 & 89.9 & 109.3 & 3.11 & $<0.001$ & 0.07 & 0.61 \\
\hline \multicolumn{9}{|l|}{ Balance } \\
\hline Total-N & 6.9 & 2.7 & 12.8 & 11.8 & 8.33 & 0.72 & 0.36 & 0.83 \\
\hline EAA-N & 12.3 & 18.2 & 13.3 & 20.3 & 4.17 & 0.11 & 0.69 & 0.88 \\
\hline NEAA-N & -5.4 & -15.5 & -0.5 & -8.6 & 4.51 & 0.05 & 0.20 & 0.79 \\
\hline Group 1 & 0.5 & 0.1 & 0.6 & 0.5 & 0.54 & 0.54 & 0.60 & 0.81 \\
\hline Group 2 & 11.4 & 17.9 & 11.8 & 19.1 & 3.20 & 0.04 & 0.79 & 0.89 \\
\hline Group 3 & -5.3 & -15.3 & -0.2 & -8.3 & 4.80 & 0.01 & 0.21 & 0.82 \\
\hline
\end{tabular}

${ }^{1}$ Least squares means presented with pooled SEM, given for $\mathrm{n}=3$; milk output was estimated from milk collected from the half udder on the evening of the Leu kinetic day (17 observations: control $=5, \mathrm{CN}=3$, $\mathrm{C} 3=5, \mathrm{CN}+\mathrm{C} 3=4) \cdot P=$ probability corresponding to the null hypothesis with $\mathrm{CN}, \mathrm{C} 3$, and $\mathrm{CN} \times \mathrm{C} 3$ contrasts.

${ }^{2}$ Total nitrogen $($ total-N $)=\mathrm{N}-\mathrm{His}+\mathrm{N}-\mathrm{Ileu}+\mathrm{N}-\mathrm{Leu}+\mathrm{N}-\mathrm{Lys}+\mathrm{N}-\mathrm{Met}+\mathrm{N}-\mathrm{Phe}+\mathrm{N}-\mathrm{Th} r+\mathrm{N}-\mathrm{Trp}+\mathrm{N}-\mathrm{Val}$ $+\mathrm{N}-\mathrm{Ala}+\mathrm{N}$-Arg $+\mathrm{N}-\mathrm{Asp}+\mathrm{N}-\mathrm{Cys}+\mathrm{N}$-Glu $+\mathrm{N}$-Gln $+\mathrm{N}$-Gly $+\mathrm{N}$-Pro + N-Ser + N-Tyr; essential AA nitrogen $($ EAA-N $)=\mathrm{N}-\mathrm{His}+\mathrm{N}-\mathrm{Ileu}+\mathrm{N}-\mathrm{Leu}+\mathrm{N}-\mathrm{Lys}+\mathrm{N}-\mathrm{Met}+\mathrm{N}-\mathrm{Phe}+\mathrm{N}-\mathrm{Th} r+\mathrm{N}-\mathrm{Trp}+\mathrm{N}-\mathrm{Val}$; nonessential AA nitrogen $($ NEAA-N) $=\mathrm{N}-\mathrm{Ala}+\mathrm{N}-\mathrm{Arg}+\mathrm{N}-\mathrm{Asp}+\mathrm{N}-\mathrm{Cys}+\mathrm{N}-\mathrm{Glu}+\mathrm{N}-\mathrm{Gln}+\mathrm{N}-\mathrm{Gly}+\mathrm{N}-\mathrm{Pro}+\mathrm{N}-\mathrm{Ser}+\mathrm{N}-\mathrm{Tyr}$; group $1=\mathrm{N}$-His $+\mathrm{N}$-Phe $+\mathrm{N}$-Met $+\mathrm{N}$-Tyr $+\mathrm{N}$-Trp; group $2=\mathrm{N}$-Ileu $+\mathrm{N}-\mathrm{Leu}+\mathrm{N}-\mathrm{Val}+\mathrm{N}$-Lys; group $3=$ $\mathrm{N}-\mathrm{Ala}+\mathrm{N}-\mathrm{Arg}+\mathrm{N}-\mathrm{Asp}+\mathrm{N}-\mathrm{Cys}+\mathrm{N}-\mathrm{Glu}+\mathrm{N}-\mathrm{Gln}+\mathrm{N}-\mathrm{Gly}+\mathrm{N}-\mathrm{Pro}+\mathrm{N}-\mathrm{Ser}$.

In this study, MG ILR accounted for 38 to $43 \%$ of whole-body ILR, as previously reported in dairy cows (37 to 44\%, Bequette et al., 1996a; 41 to $43 \%$, Thivierge et al., 2002), confirming the major contribution of the MG to whole-body metabolism. The MG also played a major role in whole-body Leu oxidation, accounting for 40 to $50 \%$ across the range of treatments studied. Certainly the gland can remove close to half of any excess supply, and in the lactating animal may therefore be more important than the other ruminant tissues known to be involved in Leu catabolism (Goodwin et al., 1987). Estimated synthesis of constitutive protein by the MG averaged $975 \mathrm{~g} / \mathrm{d}$, indicating the high turnover rate of constitutive protein in the MG.

Net Uptake of AA. The use of precise analytical techniques to measure AA concentrations in the current study also allows examination of how $\mathrm{CN}$ and $\mathrm{C} 3$ modified the net mammary uptake of individual AA to support the increased milk protein yield generated.

Effect of $\boldsymbol{C N}$. Treatment effects on arterial AA concentrations have already been discussed in a previous paper (Raggio et al., 2006). Across the MG, the arteriovenous differences increased for almost all EAA with
$\mathrm{CN}$ infusions, as previously reported with infusions of CN ranging from 177 to 762 g/d (Clark et al., 1977; Guinard and Rulquin, 1994; Vanhatalo et al., 2003b). In these studies, net uptake, calculated from reported arterio-venous differences and PF, increased with CN infusions. Despite the $\mathrm{CN}$-induced decrease in $\mathrm{PF}$ in the current experiment, $\mathrm{CN}$ treatments also increased the net uptake of all EAA.

Mepham (1982) divided AA into 3 groups, each having a different metabolism within the MG. Group 1 includes His, Met, Phe + Tyr, Thr, and Trp, and for these AA their stoichiometric transfer yields uptake:output ratios close to unity (e.g., 1.14, Guinard and Rulquin, 1994; 1.02, Miettinen and Huhtanen, 1997; 0.95, Raggio et al., 2004). The differences between studies might be due to the different energy or protein status of the animals as well as to different methodologies, including blood flow measurement (probe, Fick principle, $p$-aminohippurate), AA analyses (number of samples taken, use of individual or pooled samples, analysis technique), and frequency of blood sampling relative to feeding protocols. Because of uncertainties of whether Thr belongs to this group (Lapierre et al., 
2005), Thr was not included in group 1 calculations. In line with the concept of Mepham, MG uptake of group 1 AA increased to maintain at unity (0.99) the uptake:output ratio as milk protein production changed. This supports previous reports in which, with additional protein supply, the udder extracted these AA in ratios equal to their secretion in milk protein (Guinard and Rulquin, 1994; Vanhatalo et al., 2003a; Raggio et al., 2004).

The second group discussed by Mepham (1982) included EAA usually taken up in excess by the MG relative to milk output, namely, Ile, Leu, and Val (the branched-chain AA) and Lys (Clark et al., 1977; Guinard and Rulquin, 1994; Raggio et al., 2004). Arginine was not considered an EAA and was therefore not included in group 2 calculations. Casein infusions resulted in an increased uptake:output ratio for the group $2 \mathrm{AA}$, from 1.28 to 1.34 , comparable to other findings (e.g., from 1.41 to 1.53, Clark et al., 1977; from 1.21 to 1.64, Guinard and Rulquin, 1994; from 1.57 to 1.61, Vanhatalo et al., 2003a; from 1.33 to 1.50, Vanhatalo et al., 2003b).

For many of the AA of the third group, which constitute the NEAA (except Tyr), uptake was far less than output under basal conditions (Table 5), except for Gln and Ala (close to balance) and Gly (net release). For Arg (here considered as a NEAA), uptake was consistently in excess of output. Casein infusions increased net uptakes of Gln, Gly, and Pro, whereas Ala and Glu net uptakes decreased. Vanhatalo et al. (2003a) also observed a decrease of Glu uptake, but no change in Ala uptake, with $350 \mathrm{~g}$ of CN. Overall, for group $3 \mathrm{AA}$, net uptake increased less than the output in milk in response to $\mathrm{CN}$ infusions, leading to a greater deficit in uptake relative to output (Table 6).

Therefore, the MG responded to the increased demand for NEAA for milk protein synthesis with CN supply by increasing the uptake of the EAA of group 2 to a greater extent than the net uptake of the NEAA per se. Based on transfers of AA present in milk protein, these increases were enough to achieve a close overall balance for $\mathrm{N}$ transactions in the MG. Why the gland increases uptake of group 2 AA to restore balance instead of extracting more NEAA from the blood during CN supplementation remains a mystery. Obviously, this is not due to a lack of NEAA, as both NEAA and EAA were supplied through infusion of CN. In addition, it has been shown, using tracer kinetics, that for certain NEAA in which the net uptake:output ratios were less than unity across the caprine MG, there was isotopic dilution between the artery and vein (Bequette et al., 1997). This means that although the MG extracted only a proportion of the NEAA needed to support milk protein output, there was sufficient de novo synthesis of these AA within the MG to create an excess that was then released into the mammary vein. This may suggest that de novo synthesis is an important process within the MG when there is a general excess of AA. Whatever the reason, the metabolism of the MG adjusts to produce more milk protein from an extra protein supply by using additional $\mathrm{N}$ from those EAA extracted in excess to synthesize NEAA rather than increasing, on a net basis, the extraction of NEAA.

Effect of C3. When C3 was infused, there were differences in how the MG achieved $\mathrm{N}$ balance. Here, PF increased, regardless of whether determined by the Fick principle (Clark et al., 1977; Huhtanen et al., 2002; Vanhatalo et al., 2003b) or through the use of flow probes (Rulquin et al., 2004). Although net uptake of group $1 \mathrm{AA}$ increased to parallel the extra milk protein output, the largest changes were observed with group 3 AA. The uptake:output ratio of both Ala and Glu increased to considerably exceed unity. These changes, coupled with an increased net uptake of some of the other NEAA, as also observed for Ala (Clark et al., 1977) and Pro (Vanhatalo et al., 2003b; Rulquin et al., 2004), were sufficient to reduce the deficit for group $3 \mathrm{AA}$ (Table 6). Therefore, the mechanisms that operate to stimulate milk protein output in the absence of an extra protein supply (i.e., solely with energy provision) involve increased MG uptake of some AA of group 3. This contrasts with the response to an increased protein supply, in which uptake of group $2 \mathrm{AA}$ is augmented. Again, this suggests that the MG may be an important site within the body for removal of excess group $2 \mathrm{AA}$, and the transfer of their $\mathrm{N}$ and $\mathrm{C}$ structures to form group 3 AA may be part of the homeostatic process. Confirmation of this concept requires more detailed studies on transport kinetics and N transfer within the MG. Such approaches would also help unravel how different pathways respond to changes in the protein and energy supply.

\section{Peptide Release}

Our second objective was to examine the fate of Leu uptake under conditions similar to those reported in which uptake of Leu was greatly in excess of milk output and in which there was an unaccounted for AA balance, hypothesized as a release of peptides by the MG (Guinard and Rulquin, 1994; Rulquin et al., 2004). Within the current study, the various metabolic fates of Leu were quantified, permitting a complete balance for this AA. In the control cows, all the Leu extracted by the MG was secreted as milk or oxidized. Furthermore, the extra uptake observed with an increased protein supply was also directed toward these 2 metabolic pathways. In all treatments, the Leu unaccounted for 
across the MG (the difference between uptake plus movement from MOP minus oxidation minus milk) was small and not significantly different from zero. Similarly, the $\mathrm{N}$ balance across the $\mathrm{MG}$ for $\mathrm{AA}$ used for protein synthesis (without Asn) was not different from 0 . Thus, there was no need to invoke an additional metabolic route via peptide release into the mammary vein. This is similar to the finding of Lapierre et al. (2005) in which increased Lys-N uptake was quantitatively used for mammary synthesis of NEAA and in which it was also unnecessary to hypothesize the export of peptides.

\section{CONCLUSIONS}

The responses in milk protein output when $\mathrm{CN}$ or $\mathrm{C} 3$ was supplied to a basal ration involve different mechanisms within the MG. Both treatments increased the mammary Leu ILR, but the response was greater when $\mathrm{CN}$ was infused, and was accompanied by increased oxidation. During CN infusions, $\mathrm{N}$ balance across the MG was mainly achieved by increased uptake of group 1 and 2 AA, but during C3 supplementation this was accomplished by increased uptake of AA from groups 1 and 3. No evidence was found for the release of peptides by the MG.

\section{ACKNOWLEDGMENTS}

The authors gratefully thank the UMR PL, INRA, France; Y. Lebreton for surgeries; P. Lamberton and his team for technical support and animal care during the experiment; C. Nahuet, L. Finot, N. Huchet, I. Jicquel, and S. Rigault for their help in laboratory analyses; and, from the Rowett Research Institute, A. G. Calder and S. E. Anderson for mass spectrometric analyses. The authors also wish to acknowledge the financial support of the INRA, the European Union for the award of Marie Curie Training Site funding to the Rowett Research Institute, the Scottish Executive Environment and Rural Affairs Department (Edinburgh, Scotland, UK), the National Science and Engineering Research Council of Canada (Ottawa, Ontario, Canada), and Agriculture and Agri-Food Canada (Dairy and Swine R\&D Centre Contribution no. 895).

\section{REFERENCES}

AOAC (Association of Official Analytical Chemists). 2000. Official Methods of Analysis. 17th ed. AOAC International, Arlington, VA.

Bequette, B. J., J. A. Metcalf, D. Wray-Cahen, F. R. Backwell, J. D. G. Sutton, M. A. Lomax, J. C. MacRae, and G. E. Lobley. 1996a. Leucine and protein metabolism in the lactating dairy cow mammary gland: Responses to supplemental dietary crude protein intake. J. Dairy Res. 63:209-222.

Bequette, B. J., F. R. Backwell, J. C. MacRae, G. E. Lobley, L. A. Crompton, J. A. Metcalf, and J. D. Sutton. 1996b. Effect of intrave- nous amino acid infusion on leucine oxidation across the mammary gland of the lactating goat. J. Dairy Sci. 79:2217-2224.

Bequette, B. J., F. R. C. Backwell, A. G. Calder, J. A. Metcalf, D. E. Beever, J. C. MacRae, and G. E. Lobley. 1997. Application of a $\mathrm{U}^{13} \mathrm{C}$-labeled amino acid tracer in lactacting dairy goat for simultaneous measurements of the flux of amino acids in plasma and the partition of amino acids to the mammary gland. J. Dairy Sci. 80:2842-2853.

Bequette, B. J., F. R. Backwell, C. E. Kyle, A. G. Calder, V. Buchan, L. A. Crompton, J. France, and J. C. MacRae. 1999. Vascular sources of phenylalanine, tyrosine, lysine, and methionine for casein synthesis in lactating goats. J. Dairy Sci. 82:362-377.

Bequette, B. J., C. E. Kyle, L. A. Crompton, S. E. Anderson, and M. D. Hanigan. 2002. Protein metabolism in lactating goats subjected to the insulin clamp. J. Dairy Sci. 85:1546-1555.

Biolo, G., R. Y. D. Fleming, S. P. Maggi, and R. R. Wolfe. 1995. Transmembrane transport and intracellular kinetics of amino acids in human skeletal muscle. Am. J. Physiol. 267:E467-E474.

Calder, A. G., and A. Smith. 1988. Stable isotope ratio analysis of leucine and ketoisocaproic acid in blood plasma by gas chromatography/mass spectrometry. Use of tertiary butyldimethylsilyl derivatives. Rapid Commun. Mass Spectrom. 2:14-16.

Calder, A. G., K. E. Garden, S. E. Anderson, and G. E. Lobley. 1999. Quantitation of blood and plasma amino acids using isotope dilution electron impact gas chromatography/mass spectrometry with $\mathrm{U}-{ }^{13} \mathrm{C}$ amino acids as internal standards. Rapid Commun. Mass Spectrom. 13:2080-2083.

Cant, J. P., E. J. DePeters, and R. L. Baldwin. 1993. Mammary amino acid utilization in dairy cows fed fat and its relationship to milk protein depression. J. Dairy Sci. 76:762-774.

Clark, J. H., H. R. Spires, R. G. Derrig, and M. R. Bennink. 1977. Milk production, nitrogen utilization and glucose synthesis in lactating cows infused postruminally with sodium caseinate and glucose. J. Nutr. 107:631-644.

Goodwin, G. W., W. Gibboney, R. Paxton, R. A. Harris, and J. A. Lemons. 1987. Activities of branched-chain amino acid aminotransferase and branched-chain 2-oxo acid dehydrogenase complex in tissues of maternal and fetal sheep. Biochem. J. 242:305-308.

Guinard, J., H. Rulquin, and R. Vérité. 1994. Effect of graded levels of duodenal infusions of casein on mammary uptake in lactating cows. 1. Major nutrients. J. Dairy Sci. 77:2221-2231.

Guinard, J., and H. Rulquin. 1994. Effect of graded levels of duodenal infusions of casein on mammary uptake in lactating cows. 2. Individual amino acids. J. Dairy Sci. 77:3304-3315.

Hanigan, M. D., J. P. Cant, D. C. Weakley, and J. L. Beckett. 1998. An evaluation of postabsorptive protein and amino acid metabolism in the lactating dairy cow. J. Dairy Sci. 81:3385-3401.

Huhtanen, P., A. Vanhatalo, and T. Varvikko. 2002. Effects of abomasal infusions of histidine, glucose, and leucine on milk production and plasma metabolites of dairy cows fed grass silage diets. J. Dairy Sci. 85:204-216.

Hurtaud, C., H. Rulquin, and R. Vérité. 1998. Effects of level and type of energy source (volatile fatty acids or glucose) on milk yield, composition and coagulating properties in dairy cows. Reprod. Nutr. Dev. 38:315-330.

INRA (Institut National de la Recherche Agronomique). 1989. Ruminant Nutrition: Recommended Allowances and Feed Tables. $R$. Jarrige, ed. J. Libbey Eurotext, Paris, France.

ISO (International Organization for Standardization). 1999 (2000). ISO 9622: Whole milk. Determination of milk fat, protein and lactose content. Guidance on the operation of mid-infrared instruments. ISO, Geneva, Switzerland.

Lapierre, H., L. Doepel, E. Milne, and G. E. Lobley. 2005. Effect of lysine (Lys) supply on its utilization by the mammary gland. J. Anim. Sci. 83/J. Dairy Sci. 88(Suppl. 1):89. (Abstr.)

Linzell, J. L. 1974. Mammary blood flow and methods of identifying and measuring precursors of milk. Pages 143-220 in Lactation: A Comprehensive Treatise. The Mammary Gland/Development and Maintenance. Vol. 1. B. L. Larson, and V. R. Smith, ed. Academic Press, London, UK. 
Lobley, G. E., E. Milne, J. M. Lovie, P. J. Reeds, and K. Pennie. 1980. Whole body and tissue protein synthesis in cattle. Br. J. Nutr. 43:491-502.

Lobley, G. E., X. Shen, G. Le, D. M. Bremner, E. Milne, A. G. Calder, S. E. Anderson, and N. Dennison. 2003. Oxidation of essential amino acids by the ovine gastrointestinal tract. Br. J. Nutr. 89:617-630.

MacRae, J. C., B. J. Bequette, and L. A. Crompton. 2000. Synthesis of milk protein and opportunities for nutritional manipulation. Pages 179-199 in Milk Composition. Occasional Pub. No. 25. British Society of Animal Science, Belfast, UK.

Mepham, T. B. 1982. Amino acid utilization by lactating mammary gland. J. Dairy Sci. 65:287-298.

Metcalf, J. A., J. D. Sutton, E. J. Cockburn, D. J. Napper, and D. E. Beever. 1991. The influence of insulin and amino acid supply on amino acid uptake by the lactating bovine mammary gland. J. Dairy Sci. 74:3412-3420.

Miettinen, H. O., and P. J. Huhtanen. 1997. Effects of silage fermentation and post-ruminal casein supplementation in lactating dairy cows: 2-Energy metabolites and plasma amino acids. J. Sci. Food Agric. 74:459-468.

NRC (National Research Council). 2001. Nutrient Requirements of Dairy Cattle. 7th rev. ed. Natl. Acad. Sci., Washington, DC.

Raggio, G., D. Pacheco, R. Berthiaume, G. E. Lobley, D. Pellerin, G. Allard, P. Dubreuil, and H. Lapierre. 2004. Effect of level of metabolizable protein on splanchnic flux of amino acids in lactating dairy cows. J. Dairy Sci. 87:3461-3472.

Raggio, G., G. E. Lobley, S. Lemosquet, H. Rulquin, and H. Lapierre. 2006. Effect of casein and propionate supply on whole body protein metabolism in lactating dairy cows. Can. J. Anim. Sci. 86:81-89.
Read, W. W., M. A. Read, M. J. Rennie, R. C. Griggs, and D. Halliday. 1984. Preparation of $\mathrm{CO}_{2}$ from blood and protein-bound amino acid carboxyl groups for quantification and ${ }^{13} \mathrm{C}$-isotope measurements. Biomed. Mass Spectrom. 11:348-352.

Rigout, S., S. Lemosquet, J. E. van Eys, J. W. Blum, and H. Rulquin. 2002. Duodenal glucose increases glucose fluxes and lactose synthesis in grass silage-fed dairy cows. J. Dairy Sci. 85:595-606.

Rigout, S., C. Hurtaud, S. Lemosquet, A. Bach, and H. Rulquin. 2003. Lactational effect of propionic acid and duodenal glucose in cows. J. Dairy Sci. 86:243-253.

Rulquin, H., and P. M. Pisulewski. 2000. Effects of duodenal infusion of graded amounts of Leu on mammary uptake and metabolism in dairy cows. J. Dairy Sci. 83(Suppl. 1):164. (Abstr.)

Rulquin, H., S. Rigout, S. Lemosquet, and A. Bach. 2004. Infusion of glucose directs circulating amino acids to the mammary gland in well-fed dairy cows. J. Dairy Sci. 87:340-349.

SAS Institute. 1999. User's Guide: Version 8 Edition. SAS Institute, Inc., Cary, NC.

Swaisgood, H. E. 1993. Review and update of casein chemistry. J. Dairy Sci. 76:3054-3061.

Thivierge, M. C., D. Petitclerc, J. F. Bernier, Y. Couture, and H. Lapierre. 2002. Variations in mammary metabolism during the natural filling of the udder with milk over a 12 -h period between two milkings. J. Dairy Sci. 85:1839-1854.

Vanhatalo, A., T. Varvikko, and P. Huhtanen. 2003a. Effects of casein and glucose on responses of cows fed diets based on restrictively fermented grass silage. J. Dairy Sci. 86:3260-3270.

Vanhatalo, A., T. Varvikko, and P. Huhtanen. 2003b. Effects of various glucogenic sources on production and metabolic responses of dairy cows fed grass silage-based diets. J. Dairy Sci. 86:32493259 . 